\title{
Influence of Local Lime Materials and Organomineral Fertilizer on Fluted Pumpkin (Telfairia Occidentalis) Performance in an Ultisol of Southeastern Nigeria
}

\author{
O. B. Iren ${ }^{1}$, D. J. Udoh², U. O. Ufot ${ }^{2}$, J. N. Chukwuemeka'
}

\author{
${ }^{1}$ Department of Soil Science, University of Calabar, Calabar, Cross River State, Nigeria \\ ${ }^{2}$ Department of Soil Science, Akwa Ibom State University, Akwa Ibom State, Nigeria
}

\begin{abstract}
A field experiment was conducted in 2013 and 2014 cropping seasons at the University of Calabar Teaching and Research Farms in Cross River State, Nigeria to evaluate the influence of locally sourced liming materials and organomineral fertilizer on the performance of fluted pumpkin (Telfairia occidentalis). Eight treatments used were: control (no amendment), sole application of wood ash (WA), cocoa pod ash (CPA), periwinkle shells ash (PSA), organomineral fertilizer (OMF) each applied at $8 \mathrm{t} / \mathrm{ha}$ and the combinations of each of the lime materials with OMF. The experiment was laid out in a Randomized Complete Block Design with three replications. Chemical composition of the amendments used showed that the $\mathrm{pH}$ values of the materials varied in the order CPA > WA > OMF > PSA. Calcium $(\mathrm{Ca})$ and potassium $(\mathrm{K})$ contents were highest in CPA $(44.80 \mathrm{cmol} / \mathrm{kg}$, $0.17 \mathrm{cmol} / \mathrm{kg}$ ) while magnesium $(\mathrm{Mg})$ was highest in WA $(20.40 \mathrm{cmol} / \mathrm{kg})$. Results showed that lime and OMF applied separately or in combination increased soil $\mathrm{pH}$ values significantly $(\mathrm{P}<0.05)$ relative to the control with the highest value of 5.87 obtained from plots treated with OMF +WA. There were also significant increases in soil available phosphorus $(\mathrm{P})$, basic nutrients $(\mathrm{Ca}, \mathrm{Mg}, \mathrm{K})$ and base saturation. Significant $(\mathrm{P}<0.05)$ increases in growth parameters (vine length, number of leaves) and yield of fluted pumpkin were observed. The highest yield (596.82 $\mathrm{kg} / \mathrm{ha}$ ) obtained at $10 \mathrm{WAP}$ from OMF + CPA treated plot was not significantly higher than the yields of 586.67 and $577.67 \mathrm{~kg} / \mathrm{ha}$ obtained from OMF + PSA and OMF + WA treated plots, respectively. Therefore, for improved soil nutrients, sustainable and better performance of fluted pumpkin in an acid Ultisol of South Eastern Nigeria, the combination of any of the lime materials with OMF is recommended.
\end{abstract}

Keywords: Lime materials, organomineral fertilizer, soil properties, coastal plain sand soil, fluted pumpkin

\section{Introduction}

All creatures depend directly or indirectly on the soil for their sustenance. The soil provides a medium for plant growth, provides nutrients which encourages their sustainability and productivity. Thus, for crops to be productive, the soil must be able to provide a conducive physical, chemical and biological environment. Over the years, southern Cross River State soils that are developed on sand stones or coastal plain sand parent materials are strongly weathered, leached and highly acidic in nature. This is due to the predisposition of the soil to leaching and soil erosion resulting in high preponderance of hydrogen ions $\left[\mathrm{H}^{+}\right]$, aluminum ions $\left[\mathrm{Al}^{3+]}\right.$ and sulphur in the soil thus causing acidity and loss of soil nutrients such as nitrogen in large proportions (Njoku et al., 1987). One of the major causes of soil acidity in the humid tropics is the excessive losses of the basic cations by high and intensive rainfall. Besides, soil acidity can develop from continuous use of acid forming fertilizer without adequate liming programme and through heavy industrialization that lead to acid rains (Oguntoyinbo, 1990).

Soils with high acidity have the tendency of aluminum, hydrogen and manganese toxicity as well as nutrient deficiencies of calcium and magnesium. Aluminum toxicity is the most widespread problem

This article is published under the terms of the Creative Commons Attribution License 4.0

Author(s) retain the copyright of this article. Publication rights with Alkhaer Publications.

Published at: http://www.ijsciences.com/pub/issue/2016-05/

DOI: 10.18483/ijSci.1017; Online ISSN: 2305-3925; Print ISSN: 2410-4477 
as it is present in all soils and dissolved $\mathrm{Al}^{3+}$ is toxic to plants. Aluminum enters plant roots passively by osmosis and inhibits the growth of roots; root tips are thickened and lack fine branching. Liming acid soils provides a more favourable environment for plant growth by reducing toxic concentrations of available aluminum and manganese $(\mathrm{Mn})$ and increasing the microbial activity and availability of major plant nutrients. Liming is a soil amendment management strategy of applying substances to manage or raise the $\mathrm{pH}$ of the soil to a favorable level. It is the most widely used method to neutralize acidity and improve crop performance in acid soils.

Organomineral fertilizers are made up of natural components enriched and complemented with chemical elements for fast action. The organic substances act as added enrichment for the humus content of the soil.

Fluted pumpkin is often sensitive to high soil acidity in the tropics and responds well to soil amendments (Iren et al., 2013; Iren et al., 2014; Iren et al., 2015) hence is used as a test crop in this study. Fluted pumpkin is a tropical vine grown in West Africa as a leaf vegetable and for its edible seeds. It is a member of the Curcurbitaceae family and is indigenous to southern Nigeria. Although the fruit is inedible, the seeds produced by the gourds are high in protein and fats and can therefore contribute to a balanced diet.

Since the majority of farmers active in the food crop sector of southeastern Nigeria are poor and the cost of purchasing commercial lime materials is beyond their reach, there is, therefore the need to introduce agricultural practices which are cheaper and more readily available to them. The aim of the study was to determine how soil acidity could be reduced and soil nutrients improved through sole and combined use of locally sourced lime materials and organomineral fertilizer in acid Ultisol soil grown to fluted pumpkin.

\section{Materials And Methods \\ Experimental Site}

The research was conducted at the University of Calabar Teaching and Research Farm, Calabar (latitude $5^{\circ} 32^{\prime}$ and $4^{\circ} 27^{\prime} \mathrm{N}$ and longitude $7^{\circ} 15^{\prime}$ and $9^{\circ} 28^{\prime} \mathrm{E}$ ) with annual rainfall of 2000 to $3000 \mathrm{~mm}$ in two peaks giving a double maxima of rainfall with characteristic dry spell in August (Bulktrade and Investment Company Limited, 1989). The study area is characteristically under continual cultivation by researchers and students of the Faculty of Agriculture of the University and thus is low in $\mathrm{pH}$, exchangeable bases, organic carbon and total nitrogen (Iren et al., 2015).

\section{Experimental Design and Treatments}

The experimental site was manually cleared, tilled and flat beds measuring $3 \mathrm{~m} \times 1.5 \mathrm{~m}$ made. An alley of $1.2 \mathrm{~m}$ was left between blocks and $0.6 \mathrm{~m}$ between plots. The experiment was laid out in a randomized complete block design with three replications. The experiment comprised of eight treatments; control (no amendment), sole application of wood ash (WA), cocoa pod ash (CPA), periwinkle shells ash (PSA), organomineral fertilizer (OMF) each applied at $8 \mathrm{t} / \mathrm{ha}$ and the combinations of each of the lime materials with OMF. The combined treatments were made up of half of each liming materials (4 t/ha) with half of organomineral fertilizer (4 t/ha). Treatments were evenly spread on each plot surface and lightly tilled to mix evenly with the surface soil using a hand trowel. Lime treatments were applied two weeks before planting (Njoku et al., 1987), while OMF treatments were applied three days to planting.

\section{Planting and Field Maintenance}

Fluted pumpkin seeds were separated from the pulp and dried before planting. Two seeds of the fluted pumpkin were placed flat in the soil per hole at a planting distance of $50 \mathrm{~cm} \times 50 \mathrm{~cm}$. It was later thinned down to one plant per stand few days after emergence giving a plant population of 40,000 plants/ha. The experimental plots were kept weed free throughout the period of the experiment.

\section{Soil sampling and processing}

Soil samples were taken from the experimental site before and after experiment using soil auger at a depth of 0-15 cm. About 8-10 auger points were taken from each block, mixed thoroughly to make a composite sample before commencement of experiment, while one composite soil sample was taken per plot after the experiment for laboratory analysis. The soil samples were air-dried, ground and sieved with $2 \mathrm{~mm}$ sieve to remove materials greater than $2 \mathrm{~mm}$ in diameter before analysis.

\section{Field studies}

Five plants were randomly selected, tagged and used for growth measurements. Growth parameters measured include vine length and number of leaves per plant. These parameters were assessed at 4 weeks of planting (WAP) and continued at 2 weeks interval till the end of the experiment. Vine length was determined by measuring the distance from the base of the plant to the tip of the most vigorous branch on each plant with the use of a measuring tape. The number of leaves was determined by the counting of all the fully opened leaves. Weight of freshly harvested vine was taken at 4 WAP, 7 WAP and 10 WAP.

\section{Laboratory studies}

The soil samples, lime materials and the organomineral fertilizer were subjected to chemical analysis using standard procedures as described by 
Udo et al. (2009). Particle size distribution was determined by the Bouyoucous hydrometer method, using sodium hexametaphosphate as a dispersant. Soil $\mathrm{pH}$ was determined in 1:2.5 soil: water ratio with a $\mathrm{pH}$ meter. Organic carbon was determined by Walkley Black Dichromate Oxidation Method. Total nitrogen $(\mathrm{N})$ was determined by the micro-kjeldahl method. Available phosphorus (P) was extracted by the Bray 1 extraction method, and the content of $\mathrm{P}$ was determined colorimetrically using a Technico AAII auto analyser (Technico, Oakland, Calif). Exchangeable bases ( $\mathrm{K}, \mathrm{Na}, \mathrm{Ca}, \mathrm{Mg}$ ) were extracted with $0.1 \mathrm{~N}$ ammonium acetate, $\mathrm{K}$ and $\mathrm{Na}$ were read with a flame photometer while $\mathrm{Ca}$ and $\mathrm{Mg}$ were determined through the EDTA titration method. Exchangeable acidity was determined by leaching the soils with $1 \mathrm{~N} \mathrm{KCl}$ and titrating aliquots with 0.01 $\mathrm{NaOH}$. Effective cation exchange capacity (ECEC) was calculated as the sum of $\mathrm{Ca}, \mathrm{Mg}, \mathrm{K}$ and $\mathrm{Na}$ and exchangeable acidity. Base saturation was calculated by dividing the sum of exchangeable bases by ECEC and multiplying by 100 .

Data collected were analyzed according to the procedures outlined by Gomez and Gomez (1984) for randomized complete block design using Genstat package and significant means were compared using Fisher's least significant difference (FLSD) at $5 \%$ level of probability.

\section{Results and Discussion \\ Properties of the soil and materials used for the experiment}

Table 1 presents data on properties of the soil before experiment. The soil used was extremely acid with $\mathrm{pH}$ in water as low as 4.0 and loamy sand in texture. The soil was generally low in organic carbon (11.8 $\mathrm{g} / \mathrm{kg})$, total nitrogen $(1.0 \mathrm{~g} / \mathrm{kg})$, exchangeable bases, ECEC $(9.84 \mathrm{cmol} / \mathrm{kg})$ and base saturation $(26.02 \%)$ but moderate in available phosphorus $(15.13 \mathrm{mg} / \mathrm{kg})$, when compared to the critical minimum for Nigerian soils (Aduayi et al., 2002). The low organic carbon and total nitrogen contents could be attributed to continuous cropping of the soil without adequate fallow period or additional nutrient supply. The low levels of nutrients obtained in the experimental soils indicate low fertility status which necessitates the need for additional nutrient supply.

From the result of the nutrient composition of the liming materials and organomineral fertilizer (Table 2 ), all the materials indicated alkaline reaction when tested in water slurry. Cocoa pod ash (CPA) had the highest $\mathrm{pH}$ value of 12.60, followed by organomineral (OM) (10.90), while organomineral fertilizer had the highest total $P$ value of $117 \mathrm{mg} / \mathrm{kg}$. The ash materials had lower total $\mathrm{N}$ content than the unburnt materials indicating volatilization of $\mathrm{N}$ during the burning process.

\section{Effects of lime and organomineral fertilizer on soil properties}

The effects of sole and combined applications of liming materials and organomineral fertilizer are shown in Table 3. Application of organomineral fertilizer and lime materials either singly or in combination significantly $(\mathrm{P}<0.05)$ increased soil $\mathrm{pH}$ from the initial $\mathrm{pH}$ value of 4.0 (before experiment) and from 4.07 obtained in control plot to values ranging from 4.67 to 5.87 with the highest value obtained from the combination of organomineral fertilizer with wood ash (OMF + WA). This is in line with the findings of Nwachukwu et al. (2012) who reported highest increase in soil $\mathrm{pH}$ in plots treated with combined application of manure and ash than their sole application in an Ultisol of South Eastern Nigeria. Increases in $\mathrm{pH}$ values in Ultisol of South Eastern Nigeria soil using agricultural lime had also been reported by many researchers (Onyegbule et al., 2012; Bello and Udofia, 2013). Akinmutimi and Osodeke (2013) also reported increases in soil $\mathrm{pH}$ in an Ultisol of South Eastern Nigeria using ashes of varied origin.

Soil organic carbon contents were significantly $(\mathrm{P}<$ 0.05 ) affected by all the treatments compared with control and significant differences existed amongst all the treatments with the highest value of $19.6 \mathrm{~g} / \mathrm{kg}$ obtained from OMF + WA treated plot. There was also a significant increase $(\mathrm{P}<0.05)$ in available $\mathrm{P}$ relative to control, with the application of cocoa pod ash (CPA) alone recording the highest value of 41.88 $\mathrm{mg} / \mathrm{kg}$ although not significantly higher than the other treatments. There were significant $(\mathrm{P}<0.05)$ increases in the exchangeable calcium (Ca), magnesium $(\mathrm{Mg})$ and potassium $(\mathrm{K})$ contents with the combined application of organomineral and wood ash (OMF + WA) giving the highest values of 6.92, 2.22 and $0.150 \mathrm{cmol} / \mathrm{kg}$, respectively. The base saturation (BS) levels of the treated soils were significantly $(\mathrm{P}<0.05)$ increased to values above 50 $\%$ compared to $26.02 \%$ and $35.42 \%$ obtained before experiment and from control plot, respectively. Onwuka et al. (2009) and Akinmutimi and Osodeke (2013) have shown that ash materials contain exchangeable cations, which are known to increase soil $\mathrm{pH}$. Organomineral fertilizers are also high in these exchangeable cations and nutrients (Amosu and Okogun, 2011). Therefore, a combination of ash with OMF led to further increase in soil $\mathrm{pH}$ and soil nutrients than ash alone. The increases in soil nutrients obtained in this study as a result of the amendments applied are similar to those reported by Onyegbule et al., (2012) and Nwachukwu et al. (2012). There was general reduction in exchangeable acidity values in treated plots relative to control. This is in agreement with the findings of many researchers (Onyegbule et al., 2012; Nwachukwu et al., 2012; 
Akinmutimi and Osodeke, 2013) who reported reduction in exchange acidity by liming as remedy to soil acidity problems associated with Ultisols of South Eastern Nigeria. However, there were no significant increases $(\mathrm{P}>0.05)$ in total nitrogen, exchangeable sodium and effective cation exchange capacity (ECEC) by treatments.

Effects of lime and organomineral fertilizer on growth and yield of fluted pumpkin

Application of lime and OMF singly or in combinations resulted in significant increases $(\mathrm{P}<0.05)$ in the vine length and number of leaves per fluted pumpkin plant relative to control across all the growth stages except at 4 weeks after planting (WAP) where there was no significant increase in number of leaves. The combined treatments recorded higher values than their single applications (Table 4).

The fresh yield of fluted pumpkin was significantly $(\mathrm{P}<0.05)$ increased across all the stages of growth as a result of the treatments applied relative to control, with higher yields also obtained from combined application of lime and OMF (Table 5). The highest yield of $596.82 \mathrm{~kg} / \mathrm{ha}$ obtained at $10 \mathrm{WAP}$ was from $\mathrm{OMF}+\mathrm{CPA}$ treated plot although not significantly higher than the yields of 586.67 and $577.67 \mathrm{~kg} / \mathrm{ha}$ obtained from $\mathrm{OMF}+\mathrm{PSA}$ and $\mathrm{OMF}+\mathrm{WA}$ treated plots, respectively but was significantly higher than the yields obtained from the sole applied plots. This means that the combined treatments have double source of soil nutrients from OMF and ash, which thereby promotes the growth and yield of fluted pumpkin more than their single application(Iren et $a l ., 2013)$. The superiority of the sole and combined treatments over control may have been due to increased microbial activity and availability of major plant nutrients as a result of the lowering of the soil $\mathrm{pH}$ (Asawalam and Onyegbule, 2009; Bello and Udofia, 2013) thereby improving the soil condition and ensuring balance nutrition. Ubi et al. (2015) reported significant increase in number and sizes of pods of soy bean plants under lime over those without lime.

\section{Conclusion}

This study showed that the efficiency of organomineral fertilizer will be enhanced when combined with lime in an acid Ultisol soil for improved fluted pumpkin production. Therefore, for improved soil nutrients, sustainable and better performance of fluted pumpkin in an acid Ultisol of Southeastern Nigeria, the combination of any of the lime materials (ash) with organomineral fertilizer is recommended.

Table1: Properties of Soil before Experiment.

\begin{tabular}{ll}
\hline Parameter & Value \\
\hline Sand $(\%)$ & 84 \\
Silt $(\%)$ & 13 \\
Clay $(\%)$ & 3 \\
Texture & Loamy sand \\
$\mathrm{pH}\left(\mathrm{H}_{2} \mathrm{O}\right)$ & 4.0 \\
Org. C $(\mathrm{g} / \mathrm{kg})$ & 11.8 \\
Total N $(\mathrm{g} / \mathrm{kg})$ & 1.0 \\
Av.P $(\mathrm{mg} / \mathrm{kg})$ & 15.13 \\
Exchangeable cations $(\mathrm{cmol} / \mathrm{kg})$ & \\
$\mathrm{Ca}{ }^{2+}$ & 2.0 \\
$\mathrm{Mg}^{2+}$ & 0.4 \\
$\mathrm{~K}^{+}$ & 0.09 \\
$\mathrm{Na}^{+}$ & 0.07 \\
Exchangeable acidity $(\mathrm{cmol} / \mathrm{kg})$ & 7.28 \\
$\mathrm{ECEC}^{+}$ & 9.84 \\
$\mathrm{~B} . \mathrm{S}(\%)$ & 26.02
\end{tabular}

ECEC $=$ Effective Cation Exchange Capacity, B.S = Base Saturation. 
Influence of Local Lime Materials and Organomineral Fertilizer on Fluted Pumpkin (Telfairia Occidentalis) Performance in an Ultisol of Southeastern Nigeria

Table 2: Nutrient Composition of the Liming Materials and Organomineral Fertilizer

\begin{tabular}{lllllll}
\hline \multirow{2}{*}{ Parameter } & \multicolumn{7}{l}{ Material } & \multicolumn{1}{l}{} \\
\cline { 2 - 6 } & CPA & CPU & PSA & PSU & WA & OMF \\
\hline $\mathrm{pH}\left(\mathrm{H}_{2} \mathrm{O}\right)$ & 12.60 & 78.40 & 9.20 & 10.50 & 12.4 & 10.90 \\
Org. C $(\mathrm{g} / \mathrm{kg})$ & 35.9 & 69.4 & 15.8 & 38.6 & 32.5 & 35.9 \\
Total N $(\mathrm{g} / \mathrm{kg})$ & 2.31 & 3.80 & 0.80 & 1.01 & 2.60 & 2.90 \\
Total P $(\mathrm{mg} / \mathrm{kg})$ & 29.88 & 107.88 & 6.25 & 8.13 & 46.87 & 117.00 \\
Total Ca $(\mathrm{mg} / \mathrm{kg})$ & 44.80 & 3.30 & 20.60 & 11.80 & 26.6 & 6.20 \\
Total $\mathrm{Mg}(\mathrm{mg} / \mathrm{kg})$ & 3.60 & 18.90 & 9.60 & 2.00 & 15.6 & 19.40 \\
& & & & & & \\
Total $\mathrm{Na}(\mathrm{mg} / \mathrm{kg})$ & 0.12 & 0.11 & 0.10 & 0.11 & 0.13 & 1.10 \\
Total K $(\mathrm{mg} / \mathrm{kg})$ & 0.17 & 0.16 & 0.15 & 0.13 & 0.28 & 0.13 \\
\hline
\end{tabular}

$\mathrm{CPA}=$ Cocoa pod ash, $\mathrm{CPU}=$ cocoa pod unburnt, $\mathrm{PSA}=$ periwinkle shell ash, $\mathrm{PSU}=$ periwinkle shell unburnt, WA = wood ash, $\mathrm{OMF}=$ organomineral fertilizer

Table3: Effects of local liming materials and organomineral fertilizer on soil properties.

$\mathrm{CPA}=$ cocoa pod ash, $\mathrm{PSA}=$ periwinkle shell ash, $\mathrm{WA}=$ wood ash, $\mathrm{OMF}=$ organomineral fertilizer, $\mathrm{OMF}+\mathrm{CPA}=$ organomineral + cocoa pod ash, $\mathrm{OMF}+\mathrm{PSA}=$ organomineral + periwinkle shell ash, $\mathrm{OMF}+\mathrm{WA}=$ organomineral +

\begin{tabular}{|c|c|c|c|c|c|c|c|c|c|c|c|}
\hline \multirow[t]{2}{*}{ Treatment } & \multirow{2}{*}{$\begin{array}{l}\mathrm{pH} \\
\left(\mathrm{H}_{2} \mathrm{O}\right)\end{array}$} & \multirow{2}{*}{$\begin{array}{l}\text { Org. C } \\
(\mathrm{g} / \mathrm{kg})\end{array}$} & \multirow{2}{*}{$\begin{array}{l}\text { Total N } \\
(\mathrm{g} / \mathrm{kg})\end{array}$} & \multirow{2}{*}{$\begin{array}{l}\text { Av. P } \\
(\mathrm{mg} / \mathrm{kg})\end{array}$} & \multicolumn{4}{|c|}{ Exchangeable Bases $(\mathrm{cmol} / \mathrm{kg})$} & \multirow{2}{*}{$\begin{array}{l}\text { Exch. } \\
\text { acidity } \\
(\mathrm{cmol} / \mathrm{kg})\end{array}$} & \multirow{2}{*}{$\begin{array}{l}\text { ECEC } \\
(\mathrm{cmol} / \mathrm{kg})\end{array}$} & \multirow{2}{*}{$\begin{array}{l}\mathrm{BS} \\
(\%)\end{array}$} \\
\hline & & & & & $\mathrm{Ca}^{2+}$ & $\mathrm{Mg}^{2+}$ & $\mathrm{K}^{+}$ & $\mathrm{Na}^{+}$ & & & \\
\hline CPA & 4.87 & 12.8 & 1.03 & 41.88 & 3.80 & 1.20 & 0.132 & 0.11 & 2.94 & 8.18 & 64.08 \\
\hline PSA & 5.17 & 13.9 & 1.20 & 35.17 & 5.60 & 1.80 & 0.130 & 0.09 & 3.74 & 11.36 & 67.08 \\
\hline WA & 5.43 & 18.0 & 1.50 & 29.87 & 5.63 & 1.07 & 0.129 & 0.10 & 2.83 & 9.78 & 71.06 \\
\hline $\mathrm{OMF}$ & 4.67 & 15.7 & 1.06 & 33.92 & 3.60 & 0.97 & 0.100 & 0.20 & 4.17 & 8.94 & 53.36 \\
\hline $\mathrm{OMF}+\mathrm{CPA}$ & 5.30 & 13.3 & 1.06 & 30.38 & 6.40 & 2.00 & 0.110 & 0.03 & 3.62 & 12.16 & 70.23 \\
\hline $\mathrm{OMF}+\mathrm{PSA}$ & 5.20 & 12.2 & 1.10 & 30.71 & 6.87 & 1.33 & 0.119 & 0.02 & 3.33 & 11.67 & 71.46 \\
\hline $\mathrm{OMF}+\mathrm{WA}$ & 5.87 & 19.6 & 1.30 & 30.73 & 6.92 & 2.22 & 0.150 & 0.09 & 2.89 & 12.25 & 76.24 \\
\hline Control & 4.07 & 10.3 & 0.9 & 15.84 & 1.87 & 0.73 & 0.070 & 0.06 & 5.89 & 9.12 & 35.42 \\
\hline LSD (0.05) & 0.55 & 0.38 & NS & 12.98 & 2.09 & 1.02 & 0.05 & NS & 1.28 & NS & 11.48 \\
\hline
\end{tabular}

wood ash. 
Influence of Local Lime Materials and Organomineral Fertilizer on Fluted Pumpkin (Telfairia Occidentalis) Performance in an Ultisol of Southeastern Nigeria

Table 4: Effects of Local Liming Materials and Organomineral Fertilizer on growth parameters of Fluted Pumpkin

\begin{tabular}{|c|c|c|c|c|c|c|c|c|c|c|}
\hline \multirow[t]{2}{*}{ Treatments } & \multicolumn{5}{|c|}{ Vine length (weeks after planting) } & \multicolumn{5}{|c|}{ Number of leaves (weeks after planting) } \\
\hline & 4 & 6 & 8 & 10 & Mean & 4 & 6 & 8 & 10 & Mean \\
\hline CPA & 54.73 & 59.80 & 75.13 & 61.20 & 62.72 & 18.93 & 30.00 & 49.33 & 68.33 & 41.65 \\
\hline PSA & 48.47 & 59.87 & 61.93 & 46.13 & 54.10 & 18.4 & 31.00 & 48.27 & 57.93 & 38.90 \\
\hline WA & 48.32 & 58.93 & 60.84 & 52.11 & 55.05 & 17.00 & 31.92 & 49.16 & 60.12 & 39.55 \\
\hline OMF & 49.80 & 67.13 & 76.27 & 44.67 & 59.47 & 19.00 & 38.40 & 49.27 & 56.13 & 40.70 \\
\hline $\mathrm{OMF}+\mathrm{CPA}$ & 57.87 & 71.27 & 75.53 & 62.60 & 66.82 & 19.07 & 49.47 & 84.73 & 89.73 & 60.75 \\
\hline $\mathrm{OMF}+\mathrm{PSA}$ & 56.67 & 74.73 & 77.87 & 54.93 & 66.05 & 18.73 & 48.73 & 81.73 & 86.47 & 58.92 \\
\hline $\mathrm{OMF}+\mathrm{WA}$ & 55.23 & 73.22 & 75.62 & 54.75 & 64.71 & 16.50 & 52.60 & 80.50 & 86.20 & 58.95 \\
\hline Control & 32.53 & 40.41 & 46.53 & 35.27 & 38.69 & 12.60 & 19.93 & 21.27 & 27.00 & 20.20 \\
\hline LSD (0.05) & 12.65 & 14.42 & 15.28 & 14.70 & & NS & 8.6 & 9.2 & 11.6 & \\
\hline
\end{tabular}

$\mathrm{CPA}=$ cocoa pod ash, $\mathrm{PSA}=$ periwinkle shell ash, $\mathrm{WA}=$ wood ash, $\mathrm{OMF}=$ organomineral fertilizer, $\mathrm{OMF}+\mathrm{CPA}=$ organomineral + cocoa pod ash, $\mathrm{OMF}+\mathrm{PSA}=$ organomineral + periwinkle shell ash, $\mathrm{OMF}+\mathrm{WA}=$ organomineral + wood ash.

Table 5: Effects of local liming materials and organomineral fertilizer on yield of fluted

\begin{tabular}{lllll}
\multicolumn{1}{c}{ pumpkin } & \multicolumn{3}{l}{ Mean } \\
\cline { 2 - 4 } Treatments & \multicolumn{2}{l}{ Fresh shoot yield (kg/ha) } & $10 \mathrm{WAP}$ & \\
\cline { 2 - 4 } & 4WAP & & & \\
\hline CPA & 256.93 & 405.55 & 540.00 & 400.83 \\
PSA & 226.72 & 310.00 & 340.00 & 292.24 \\
WA & 224.91 & 315.62 & 339.93 & 293.49 \\
OMF & 253.46 & 342.57 & & \\
OMF+CPA & 413.76 & 482.98 & 345.00 & 313.68 \\
OMF+PSA & 356.57 & 459.50 & 596.82 & 497.85 \\
& & & 586.67 & 467.58 \\
OMF+WA & 349.01 & 452.98 & & \\
Control & 130.99 & 153.25 & 577.67 & 459.89 \\
LSD $(0.05)$ & 40.2 & 81.30 & 193.33 & 159.19
\end{tabular}

$\mathrm{CPA}=$ cocoa pod ash, $\mathrm{PSA}=$ periwinkle shell ash, $\mathrm{OMF}=$ organomineral fertilizer, $\mathrm{OMF}+\mathrm{CPA}=$ organomineral + cocoa pod ash, $\mathrm{OMF}+\mathrm{PSA}=$ organomineral + periwinkle shell ash, $\mathrm{OMF}+\mathrm{WA}=$ organomineral + wood ash. 


\section{References}

1) Aduayi, E. A., Chude, V. O., Adebusuya, B. A. and Olayiwola, S. O. (2002). Fertilizer Use and Management Practice for Crops in Nigeria. Abuja. pp 188.

2) Akinmutimi, A. L. and Osodeke, V. E. (2013). Effect of ashes of varied origin on salt replaceable and active acidity in an Ultisol of Southeast Nigeria. Proceedings of the $37^{\text {th }}$ Annual Conference of the Soil Science Society of Nigeria, Lafia, 252-262.

3) Amosu, S. A. and Okogun, J. A. (2011). Effect of organomineral and inorganic fertilizers on the nodulation and nitrogen uptake of soybean and cowpea. Nigerian Journal of Soil Science, 21(1): 85-90.

4) Asawalam, D.O. and Onyegbule, U. (2009).Effects of some Local Liming Materials and Organic Manures on some Soil Chemical Properties and Growth of Maize. Nigerian journal of Soil Science, 19(2): 71- 76.

5) Bello, O. S. and Udofia, A. E. (2013). Effect of liming on some properties of South Eastern soils of Nigeria. Nigerian Journal of Soil Science, 23 (1): 124-129.

6) Bulktrade and Investment Company Limited (1989). Soils and land use survey of Cross River State, Ministry of Agriculture and Natural Resources, Cross River State, Nigeria, 376pp.

7) Iren, O. B., John, N. M. and Imuk, E. A. (2013). Effects of Sole and Combined Applications of Organic Manures and Urea on Growth, Crude Protein and Nutrient Uptake of Fluted Pumpkin (Telfairia occidentalis, Hook f.). Journal of Agriculture, Forestry and Environment, 2(1): 78-85.

8) Iren, O. B., John, N. M. and Imuk, E. A. (2013). Influence of rates of pig manure and NPK $(15: 15: 15)$ fertilizer on soil chemical properties and dry matter yield of Fluted Pumpkin (Telfairia occidentalis, Hook f.). Nigerian Journal of Soil and Environmental Research, 11: 55-59.

9) Iren, O. B., John, N. M. and Imuk, E. A. (2014). Effects of sole and combined applications of organic manures and urea on soil properties and yield of fluted pumpkin (Telfairia occidentalis, Hook f.), Nigerian Journal of Soil Science, 24(1): 125 - 133

10) Iren, O. B., Uwah, I. D. and Ekpenyong, V. E. (2015) Response of fluted pumpkin (Telfairia occidentalis, hook f.) to different levels of poultry manure application in an ultisol of southeastern Nigeria. Journal of Organic Agriculture and Environment, 3: 5-14.

11) Njoku, B. O., Enwezor, W. O. and Onyeanakwe, B. I. (1987) Calcium Deficiency identified as an important factor limiting Maize growth in acid Ultisolsof Eastern Nigeria. Ferti. Resource, 14: 113-124

12) Nwachukwu, O. I., Nyong, A. E. and Opara, U. D. (2012). Effect of manures and ash on soil properties, yield and nutrient uptake of Amaranthus in an Ultisol of South East Nigeria. Nigerian Journal of Soil Science, 22(2):70-78.

13) Oguntoyinbo, O. F., (1990). Effectiveness of some Liming Materials in Nigeria as Ameliorant of Soil Acidity, Ife. Journal of Agric Science. 2:10-15.

14) Onyebule, U. N., Jiwuba, F., Ohaneje, A. and Usifo, B. C. (2012). Effect of liming on some soil properties and yield of soybean in an acid Ultisol of Mbato, South Eastern Nigeria. Nigerian Journal of Soil and Environmental Research, 11: 41-47.

15) Onwuka, M. L., Osodeke, V. E. and Ano, A. O. (2009). Use of liming materials to reduce soil acidity and affect maize growth parameters in Umudike, South East Nigeria. Production Agriculture and Technology, 5 (2): 386-296.

16) Udo, E. J., Ibia, O. T., Ogunwale, A. J., Ano, A. O.andEsu, J. E. (2009). Manual of Soil, Plant and Water Analysis.Sibon Books Limited, Lagos, Nigeria.

17) Ubi, M. W., Amalu, U. C. and Ubi, W. (2015).Effect of lime on Agronomic Traits and Yields of Soybean (Glysinemax (L) Merill) in Coastal Plain Soils of Humid Tropical Zone.(Unpublished Manuscript in press), 4-15pp.

18) Wahua, T. A.T. (1999). Applied statistics for scientific studies. Afrika-Link Books,Ibadan, 356pp. 